\title{
EVALUASI PROGRAM PEMBELAJARAN TENIS DASAR SEMESTER GANJIL 2018 FIK UNP
}

\author{
Damrah $^{1}$, Pitnawati $^{2}$, Suwirman $^{3}$ \\ ${ }^{1}$ Program Studi Pendidikan Jasmani Kesehatan dan Rekreasi, Fakultas Ilmu Keolahragaan, Universitas \\ Negeri Padang, Jalan Prof. DR. Hamka Air Tawar Barat, Padang, 25132, Indonesia \\ ${ }^{2}$ Program Studi Pendidikan Jasmani Kesehatan dan Rekreasi, Fakultas Ilmu Keolahragaan, Universitas \\ Negeri Padang, Jalan Prof. DR. Hamka Air Tawar Barat, Padang, 25132, Indonesia \\ ${ }^{3}$ Program Studi Pendidikan Jasmani Kesehatan dan Rekreasi, Fakultas Ilmu Keolahragaan, Universitas \\ Negeri Padang, Jalan Prof. DR. Hamka Air Tawar Barat, Padang, 25132, Indonesia
}

Email. damrahburhan@yahoo.co.id ${ }^{1}$, pitnawati@yahoo.co.id ${ }^{2}, \underline{\text { suwirman@fik,unp.ac.id }}^{3}$

\begin{abstract}
Abstrak
Rendahnya kualitas hasil pembelajaran tenis dasar mahasiswa yang mengambil mata kuliah tenis dasar di jurusan pendidikan olahraga FIK UNP, merupakan salah satu masalah pembelajaran yang sangat perlu dicarikan solusi agar dapat meningkatkan kualitas hasil belajar tenis mahasiswa di masa depan.Tujuan penelitian ini adalah untuk mendapatkan informasi yang akurat dan objektif tentang kualitas pembelajaran tenis dasar yang dapat dijadikan pertimbangan untuk memperbaiki proses pembelajaran tenis berikutnya. Program pembelajaran tenis dasar ini merupakan salah satu program yang dapat dijadikan percontohan untuk program pembelajaran lainnya di FIK UNP.

Metode penelitian yang digunakan adalah metode evaluasi dengan menggunakan model CIPP yang dikembangkan oleh Stufflebeam, model ini terdiri dari konteks (context), masukan (input), proses (prosess) dan hasil (product).

Hasil penelitian tentang evaluasi program pembelajaran tenis dasar ini adalah, yang pertama dari sudut konteks, bahwa konsep pembelajaran tenis dasar perlu direvisi kembali, terutama terkait dengan tingkat kedalaman materi permbelajaran yang terlalu sulit, sehingga dengan tingkat potensi mahasiswa yang masih rendah sulit terjangkau. Dari sudut input, bahwa tidak semua mahasiswa yang mengambil mata kuliah dasar memiliki bakat dan minat terhadap olahraga tenis ini, sehingga diperlukan pertimbangan dan aturan yang sesuai dengan tingkat kemampuan dan potensi mahasiswa, termasuk perhatian dosen yang perlu di tingkatkan serta memaksimalkan penggunaan fasilitas perkuliahan yang telah disiapkan oleh jurusan/ fakultas. Dari sudut proses, pengelolaan dan pengornisasian materi perlu di tata ulang, agar mahasiswa mendapatkan kesempatan yang banyak untuk belajar dan latihan, serta menggunakan metode yang lebih kompleks, karena metode yang kurang kompleks, sulit bagi mahasiswa untuk menguasai materi yang diberikan. Dari sudut hasil, bahwa secara kualitas mahasiswa belum memenuhi syarat untuk dapat lulus artinya belum berhasil, karena belum memiliki penguasaan gerak dasar tenis yang memadai untuk dapat diterima pada mata kuliah tenis pendalaman atau lanjutan.

Oleh karena itu, jika program pembelajaran tenis dasar mahasiswa jurusan FIK UNP ini dapat berjalan dengan baik, maka komponen-komponen yang telah disampaikan di atas perlu diperbaiki dan direvisi, agar kegiatan pembelajaran tenis dasar dapat berkualitas dan bermakna.
\end{abstract}

Kata Kunci : evaluasi program, pembelajaran tenis dasar, model CIPP

\section{PENDAHULUAN}

Tenis Dasar merupakan salah satu mata kuliah pilihan wajib yang di ambil oleh mahasiswa jurusan pendidikan olahraga FIK UNP. Salah satu tujuan dari mata kuliah tenis dasar ini adalah untuk menjadikan mahasiswa FIK UNP dapat bermain tenis sesuai dengan aturan permainan tenis yang telah ditetapkan dalam RPS Tenis jurusan Pendidikan Olahraga FIK UNP. Tujuan ini ditetapkan berdasarkan 
tujuan pendidikan yang telah ditetapkan secara nasional, yaitu mengembangkan pengetahuan, keterampilan dan kecerdasasan mahasiswa, agar menjadi manusia yang dapat berguna bagi masyarakat, bangsa, Negara dan agama. (UNP, 2017)

Untuk mencapai tujuan di atas, maka setiap mahasiswa diwajibkan untuk mengikuti semua proses yang telah digariskan oleh Fakultas dan Jurusan pendidikan olahraga. Proses pembelajaran ini diberikan dalam bentuk mata kuliah yang terhimpun ke dalam beberapa kelompok mata pelajaran. Tenis dasar termasuk ke dalam mata kuliah pilihan dengan beban 2 sks. Artinya bahwa setiap mahasiswa yang berminat dapat mengambil mata kuliah tenis. Dari beberapa semester sebelumnya, jumlah mahasiswa yang mengambil mata kuliah tenis dasar, cukup banyak dan rata-rata 20- 30 mahasiswa, walaupun mata kuliah ini dalam bentuk pilihan. Salah satu penyebabnya adalah mata kuliah tenis memiliki prospek dan manfaat yang relative besar dalam kegiatan yang dilakukan masyarakat dan olahraga ini termasuk olahraga yang sangat diminati oleh masyarakat banyak, baik untuk prestasi, pendidikan maupun untuk rekreasi.

Dari segi proses, mata kuliah tenis mengandung beberapa kegiatan, yaitu kegiatan tatap muka, kegiatan terstruktur dan kegiatan mandiri sesuai dengan aturan sks yang berlaku. Kegiatan tatap muka dilakukan bersama dosen sebanyak 16 kali pertemuan, termasuk med dan ujian semester. Dalam tatap muka ini, dosen bersama mahasiswa melakukan proses pembelajaran berdasarkan silabus dan RPP yang telah disusun sebelumnya. Kegiatan terstruktur merupakan kegiatan atau tugas yang diberikan kepada mahasiswa untuk belajar dan berlatih sesuai dengan materi yang diberikan dosen. Kewajiban mahasiswa dalam proses terstruktur ini adalah mengulang dan atau mendalami materi yang diberikan sebelumnya secara teratur, sehingga mahasiswa dapat memiliki kemampuan yang diharapkan sesuai dengan tujuan pembelajaran tenis. Sedangkan kegiatan mandiri merupakan kegiatan yang dilakukan oleh mahasiswa tanpa bimbingan dari dosen, namun dilakukan sendiri atau bersama sesuai dengan waktunya masing-masing.

Namun dari hasil observasi penulis terhadap mahasiswa yang pernah mengambil mata kuliah tenis dasar, banyak yang mengeluh dan menganggap mata kuliah tenis ini sulit untuk dipelajari, sehingga banyak diantara mahasiswa FIK UNP tidak dapat melanjutkan ke tingkat pendalaman. Rata-rata mahasiswa yang mengambil mata kuliah pendalaman ini antara $5 \%$ sampai $10 \%$ dari jumlah mahasiswa yang telah mengambil tenis dasar. Kenyataan yang seperti ini tidak dapat dibiarkan dan dapat mempengaruhi kualitas pendidikan secara menyeluruh. Kualitas pendidikan khususnya dalam mata kuliah tenis di jurusan pendidikan olahraga FIK UNP sangat diharapkan dapat memberikan sumbangsih pada peningkatan prestasi pertenisan di Sumatera Barat khususnya dan Indonesia umumnya.

Oleh karena itu penulis merasa terpanggil untuk melakukan penelitian terhadap pembelajaran tenis dasar di juruan pendidikan olahraga FIK UNP ini, melalui evaluasi program pembelajaran tenis dasar dengan maksud untuk mendapatkan informasi secara akurat mengenai pelaksanaan dan ketercapaian program pembelajaran tenis di jurusan pendidikan olahraga FIK UNP, sehingga dengan informasi ini akan dapat dijadikan sebagai masukan untuk perbaikan program pembelajaran berikutnya. Penelitian ini menggunakan model evaluasi CIPP (Context, Input, Process dan Product). Karena model evaluasi CIPP ini sangat relevan dengan objek penelitian, serta dapat melakukan evaluasi terhadap efektivitas program pembelajaran tenis dasar. Di samping itu diharapkan dapat memperoleh informasi yang tepat dan berguna dalam merumuskan konsepkonsep strategis dalam mengembangkan sumber daya manusia olahraga tenis. Seiring dengan itu menurut Stufflebeam (2017) penerapan setiap tipe evaluasi pada model CIPP hanya dapat digunakan jika diindikasikan informasi diluar yang sudah ada diperlukan bukan oleh nilai inheren (dalam) saja. Oleh karena itu penelitian ini sangat penting, agar asumsi dari luar dapat dijawab secara ilmiah. Penelitian yang serupa belum pernah dilakukan, sehingga diharapkan 
melalui penelitian ini dapat membantu pencapaian tujuan pembinaan tenis daerah dan nasional, sekaligus program PP Pelti dapat berjalan dengan baik dan lancar.

\section{METODE}

Metode yang digunakan dalam penelitian ini adalah evaluasi dengan menggunakan model CIPP (Context, Input, Process, Product). Penggunaan model CIPP di pilih karena model ini merupakan model evaluasi program yang sering digunakan oleh para ahli dalam mengevaluasi suatu program.

Sehingga dengan alasan ini, maka peneliti menggunakan model CIPP ini dalam mengevaluasi program pembelajaran tenis dasar di jurusan pendidikan olahraga FIK UNP. Evaluasi konteks digunakan untuk mengidentifikasi dan menilai kebutuhan, problem, aset yang mendasari disusunnya suatu program.

Evaluasi input dilakukan untuk membantu para pengambil keputusan dalam hal ini dosen tenis untuk menilai alternatif, rencana pembelajaran semester (RPS), serta perangka lainnya. Evaluasi proses dilakukan untuk membantu mengimplementasikan keputusan sampai sejauh mana rencana pembelajaran telah diterapkan.

Evaluasi produk yaitu berupaya untuk mengidentifikasi dan mengakses keluaran dan manfaat, baik yang direncanakan untuk jangka pendek maupun jangka panjang. Subjek penelitian ini adalah dosen mata kuliah tenis dasar, mahasiswa jurusan pendidikan olahraga FIK UNP yang mengambil mata kuliah tenis semester ganjil 2018, dan teman sejawat di jurusan pendidikan olahraga FIK UNP.

Penelitian ini dilakukan dengan mendeskripsikan pelaksanaan program pembelajaran yang dilakukan di jurusan pendidikan olahraga FIK UNP, kemudian dievaluasi dengan membandingkan apa yang telah dicapai dari program peningkatan prestasi atlet dengan apa yang seharusnya dicapai berdasarkan standar mutu yang telah ditetapkan oleh UNP. Adapun disain evaluasi program yang digunakan adalah sebagai berikut:

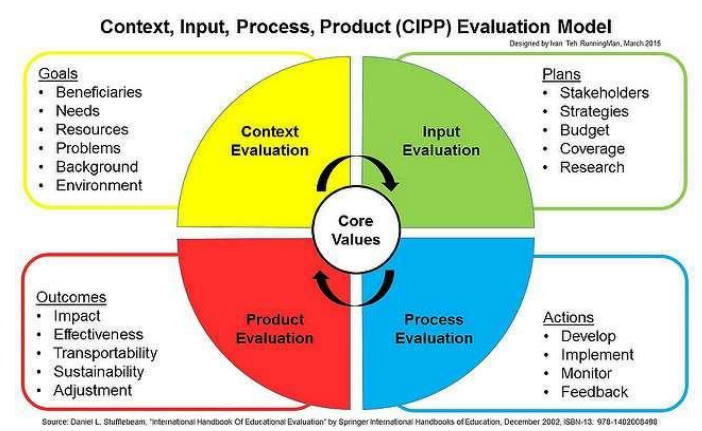

Gambar 1. Disain Evaluasi Model CIPP (Stufflebeam, 2017)

Instrumen yang digunakan untuk penelitian ini adalah wawancara, observasi dan dokumentasi serta dianalisis dengan beberapa tahapan, pertama melakukan reduksi data, yaitu dengan kondisi data yang diperoleh dari lapangan yang tidak terbatas, sehingga peneliti perlu melakukan reduksi. Hal ini dimaksudkan untuk hal-hal pokok serta tema-tema yang relevan dengan fokus penelitian, pembelajaran tenis dasar di jurusan pendidikan olahraga FIK UNP.

Setelah proses ini dilakukan, maka dilanjutkan dengan penyajian data, yaitu dalam bentuk uraian singkat dan jelas tentang pembelajaran tenis dasar, dengan didukung oleh bagan, diagram yang berhubungan dengan kategori dan sejenisnya.

Tujuan dari penyajian data ini adalah memudahkan untuk memahami apa yang terjadi di lapangan dan merencanakan kerja selanjutnya berdasarkan apa yang telah dipahami tersebut dan memungkinkan data hasil penelitian tidak tercampur dengan sejumlah data yang belum diolah. Setelah itu baru dilanjutkan dengan penarikan kesimpulan atau verifikasi, yaitu untuk mencari pola tema atau hal-hal yang sering muncul, sehingga diperoleh suatu kesimpulan yang semakin lama menjadi semakin jelas seiring dengan semakin banyaknya data yang diperoleh.

HASIL PENELITIAN DAN PEMBAHASAN

\section{Hasil Evaluasi Program Pembelajaran Tenis Dasar Mahasiswa Jurusan Pendidikan Olahraga FIK UNP ditinjau dari Komponen Konteks.}


Evaluasi konteks mengenai dasar penyusunan program pembelajaran tenis dasar mahasiswa jurusan pendidikan olahraga FIK UNP pada dasarnya merupakan program pembelajaran tenis dasar yang disusun sesuai dengan kebutuhan mahasiswa masa kini. yaitu dapat mengembangkan minat dan bakat mahasiswa dalam rangka melahirkan mahasiswa yang berkualitas dan bermanfaat bagi masyarakat. Adapun tujuan dari mata kuliah tenis dasar ini adalah agar mahasiswa memiliki kemampuan secara teori dan praktek, sehingga dengan kemampuan ini mahasiswa memiliki modal untuk dapat melanjutkan ketingkat lanjutan, minimal mahasiswa yang telah mengambil mata kuliah tenis dasar ini, sudah dapat memahami dan menjelaskan tentang olahraga tenis kepada masyarakat. Di samping itu kondisi pendukung yang telah disiapkan untuk pembelajaran tenis dasar ini antara lain adalah lapangan, raket, bola, net dan ruangan belajar serta media lainnya. Semua fasilitas ini telah disiapkan sedemikian rupa dengan tingkat kualitas yang sangat memadai. Artinya perangkat pembelajaran tenis dasar yang telah disiapkan dosen telah didukung dengan fasilitas yang disiapkan oleh fakultas, sehingga secara konteks persiapan pembelajaran tenis dasar tidak mengalami masalah yang berarti. Menurut Suharsimi Arikunto (2008) bahwa untuk mendapatkan hasil yang lebih maksimal dalam belajar dan latihan, sangat ditentukan oleh banyak factor salah satunya adalah kejelasan konsep pembelajaran dan latihan yang akan diberikan, jika konsep pembelajaran sudah ditata dengan baik, maka akan mempermudah pencapaian tujuan yang diharapkan.

\section{Hasil Evaluasi Pembelajaran Tenis Dasar Mahasiswa Jurusan Pendidikan Olahraga FIK UNP ditinjau dari Komponen Input.}

\author{
Evaluasi input terkait dengan evaluasi \\ program pembelajaran tenis dasar \\ mahasiswa, terdiri dari beberapa hal, yaitu \\ potensi mahasiswa, potensi dosen, kualitas
}

sarana prasarana dan dukungan media tehnologi dan informasi, serta perangkat pembelajaran yang tersedia. Dilihat dari potensi mahasiswa yang mengambil mata kuliah tenis dasar ini, rata-rata belum memiliki pengetahuan dan keterampilan yang memadai tentang pertenisan. Dari hasil informasi yang diperoleh, mahasiswa yang mengambil mata kuliah tenis dasar di dasari atas keinginan sendiri tanpa ada paksaan dari pihak lain untuk mendalami cabang olahraga tenis, sehingga mereka berharap dengan informasi yang diperoleh selama perkuliahan, akan dapat membantu karir mereka ke depan, karena olahraga tenis termasuk olahraga yang produktif dan dapat memberikan sumbangan terhadap kehidupan seseorang (Crespo, 2002). Sementara dosen yang mengajar tenis dasar ini adalah satu dosen senior dan dibantu oleh dua orang dosen yunior. Dosen senior adalah dosen yang sudah lama menggeluti olahraga tenis dan pembelajarannya dan telah memiliki pengalaman dan keterampilan di bidang pertenisan, sedangkan untuk dosen yunior, merupakan mantan mahasiswa yang memiliki prestasi di bidang tenis dan sudah menjadi calon PNS di jurusan pendidikan olahraga FIK UNP. Ketiga dosen inilah yang akan bertanggung jawab selama pembelajaran tenis berlangsung. Untuk kualitas sarana prasarana yang tersedia cukup memadai dan memenuhi syarat yang dibutuhkan untuk pembelajaran tenis mahasiswa, baik secara kualitas maupun kuantitas. Dukungan media dan informasi yang tersedia dapat diperoleh secara bebas dan dapat digunakan secara maksimal, hal ini sangat tergantung peluang yang diberikan oleh dosen untuk memanfaatkan sumber yang tersedia. Khusus untuk perangkat pembelajaran telah disusun oleh dosen bersangkutan sesuai dengan kebutuhan, antara lain adalah silabus, RPS, bahan ajar, sumber belajar dan media pembelajaran. Semuanya telah didokumentasi dalam satu file di jurusan pendidikan olahraga FIK UNP. Menurut UNP (2019) untuk mencapai hasil belajar sesuai dengan Capai Pembelajaran Lulusan 
(CPL) yang telah ditetapkan dalam Rencana Pembelajaran Semester (RPS) diperlukan perangkat-perangkat pembelajaran lainnya untuk membantu mahasiswa mempermudah pembelajaran. Oleh karena itu semua perangkat pembelajaran perlu disiapkan oleh masing-masing dosen secara komplek termasuk mata kuliah tenis dasar.

\section{Hasil Evaluasi Pembelajaran Tenis Dasar Mahasiswa Jurusan Pendidikan Olahraga FIK UNP ditinjau dari Komponen Proses.}

Dari data yang diperoleh melalui wawancara dan observasi serta dokumentasi yang dilakukan, maka ada beberapa hal yang dapat disampaikan terkait dengan evaluasi proses, antara lain adalah :

a. Mahasiswa yang hanya memiliki modal berdasarkan keinginan bukan karena berdasarkan bakat dan hobi, rata-rata memiliki kesulitan untuk belajar tenis karena tingkat keterampilan motorik nya masih rendah, sehingga sulit menguasai keterampilan tenis yang diberikan. Oleh karena itu sebaiknya keinginan mahasiswa harus diiringi dengan keterampilan dasar gerak, karena keterampilan gerak dasar yang dimiliki akan mempermudah keterampilan tehnik yang akan dipelajari mahasiswa. Menurut Damrah (2015) bahwa makin banyak keterampilan gerak dasar yang dimiliki oleh seseorang, akan mempermudah orang tersebut untuk melakukan keterampilan olahraga yang dipelajari. Untuk itu tingkat keterampilan gerak dasar mahasiswa perlu diketahui lebih awal sebelum mempelajari keterampilan olahraga berikutnya, sehingga objektifitas hasil pembelajaran dapat diperoleh secara jelas.

b. Selama proses berlangsung, dosen bekerja ekstra menggunakan pengayaan dan penggunaan waktu secara efektif terhadap jadwal tatap muka, terstruktur dan mandiri dalam rangka mengatasi kelemahan motorik yang dimiliki mahasiswa. Di samping itu dosen diharuskan menggunakan metode latihan yang bervariasi, yaitu drill, bermain dan simulasi baik untuk tatap muka, terstruktur dan mandiri. Artinya dosen diharuskan untuk bekerja ekstra disamping tugas yang dilakukannya secara normal untuk mendapatkan hasil yang lebih baik. Bagi dosen yang kurang memperhatikan pertemuan terstruktur dan mandiri, kondisi ini kurang efektif untuk terlaksana. Oleh karena dalam pelaksanaan kurikulum perguruan tinggi UNP (2017) menekankan agar penerapan sks perlu diterapkan secara maksimal dalam rangka menjalankan tugas ideal sebagai dosen.

c. Pemanfaatan fasilitas latihan dilaksanakan secara maksimal dengan menambah fasilitas yang mempermudah mahasiswa untuk bisa menguasai tehnik bermain, seperti menggunakan bola yang lebih ringan, raket tenis yang beraneka ragam dan lapangan mini tenis.

d. Media dan informasi tidak dapat diabaikan dan harus dimanfaatkan dan digunakan semaksimal mungkin untuk mempermudah proses pembelajaran tenis dasar.

e. Olahraga tenis bukanlah olahraga yang sulit, namun mahasiswa akan dapat mudah mempelajarinya, jika mahasiswa memiliki banyak keterampilan gerak dasar baik keterampilan lokomosi, non lokomosi dan keterampilan manipulasi.

\section{Hasil Evaluasi Pembelajaran Tenis Dasar Mahasiswa Jurusan Pendidikan Olahraga FIK UNP ditinjau dari Komponen Produks.}

Beberapa produk yang dihasilkan selama pembelajaran berlangsung (16 kali pertemuan), maka dapat diinformasikan beberapa hal, yaitu :

a. Mahasiswa yang memiliki keterampilan gerak dasar yang komplik (10 orang) dapat mencapai hasil pembelajaran tenis dasar sesuai dengan target yang 
diberikan, baik secara teori maupun secara praktek.

b. Walaupun dengan menggunakan variasi latihan dan penggunaan waktu terstruktur dan mandiri, mahasiswa yang memiliki tingkat keterampilan gerak dasar yang rendah belum dapat mencapai hasil yang ditetapkan baik secara kualitas maupun kuantitas, namun memiliki kelebihan di bidang teori. Rata-rata mahasiswa yang memiliki keterampilan gerak dasar yang kurang namun memilki keinginan yang tinggi cendrung dapat menguasai teori yang diberikan, karena mereka mampu mempelajari dan mendalami secara teori.

\section{Kesimpulan}

1. Pembelajaran tenis dasar mahasiswa jurusan pendidikan olahraga FIK UNP dapat berjalan secara efektif dan efisien, jika dosen dapat memahami karakteristik mahasiswanya secara detail di awal perkuliahan untuk menentukan strategi dan metode yang akan digunakan dalam pelaksanaan perkuliahan.

2. Sebaiknya mahasiswa yang akan mengambil mata kuliah dasar tenis, adalah mahasiswa yang memiliki pengetahuan dan keterampilan tenis atau mahasiswa yang memiliki bakat, minat dan keterampilan gerak dasar lokomosi, non lokomosi serta manipulasi yang baik, sehingga RPS yang telah direncakan dapat diserap oleh mahasiswa.

3. Bagi mahasiswa yang ingin belajar tenis tanpa didasari dengan bakat, minat dan keterampilan gerak dasar yang rendah, sebaiknya mencari mata kuliah dasar lainnya yang bersifat tidak terlalu komplik seperti atletik, bolavoli, sepakbola dan panahan.

4. Terkait dengan analisis kebutuhan dalam program pembelajaran tenis dasar, tidak terdapat perbedaan antara program pembelajaran untuk mahasiswa putra dengan mahasiswa putri. artinya semua mahasiswa memiliki kesempatan dan fasilitas yang sama, sehingga tidak ada bagi mahasiswa dan pihak lain yang menyatakan bahwa persiapan perkuliahan mengalami masalah, kecuali kondisi masing- masing mahasiswa yang kemungkinan akan berbeda, yaitu tingkat kebugaran jasmani, status gizi, kesehatan, tingkat social, budaya, ekonomi dsb. Untuk itu perlu dilakukan pendalaman lebih lanjut, melalui penelitian berikutnya.

\section{Daftar Rujukan}

Achmad Sofyan Hanif. 2011. "Evaluasi Terhadap Sekolah Khusus Olahragawan SMP/SMA Ragunan Jakarta". Cakrawala Pendidikan, Juni 2011, Th. XXX, No 2.

Damrah. 2015. "Evaluasi Program Sentra Pembinaan Tenis Sumatera Barat Dan Riau" Disertasi. Universitas Negeri Jakarta.

Crespo, Miguel dan Miley. Advanced Coaches Manual. 2002. London; Bank lane Roehampton: ITF Ltd.

Djaali, Puji Mulyono dan Ramli. 2000. Pengukuran Dalam Bidang Pendidikan. Jakarta: PPS UNJ.

Yusuf, Farida. 2008. Evaluasi Program dan Instrumen Evaluasi Untuk Program Pendidikan dan Penelitian. Jakarta: Rineka Cipta.

Guili Zhang, Nancy Zeller, Robin Griffith, Debbie Metcalf dkk. 2011. "Using the Context, Input, Process, and Pruduct Evaluation Model (CIPP) as a Comprehensive Framework to Guide the Planning, Implementation, and Assessment of Service-learning Program"

Journal of Higher Education Outreach and Engagement Volume 15 No 4. ISSN 1534-6104. Copyright by the University of Georgia. 
Firdaus, Kamal. 2011. "Evaluasi Program Pembinaan Olahraga Tenis Lapangan di Kota Padang". Jurnal Media Ilmu Keolahragaan Indonesia Volume 1. Edisi 2. Desember 2011. ISSN: 2088-6802.

Kirkpatrick D, L. \& Kirkpatrick, J.D. 2009. Evaluating Training Programs: the four levels 3rd ed. San Francisco: BerretKoehler Publishers, Inc.

Moleong, J Lexy. 2007. Metodologi Penelitian Kualitatif. Bandung: Remaja Rosdakarya.

Stufflebeam, L Daniel. 2007. CIPP Evaluation Model Checklist. San Fransisco. Jossey Bass.

2017. The CIPP Evaluation Model. New York London. The Guilford Press.

Sudjana, Djudju. 2006. Evaluasi Program Pendidikan Luar Sekolah. Bandung: PT Remaja Rosdakarya.

Suharsimi, Arikunto. 2008. Evaluasi Program Pendidikan: Pedoman Teoritis Praktis Bagi Mahasiswa dan Praktisi Pendidikan (Edisi Kedua). Jakarta: Bumi Aksara.

Prastati, Trini. 2011. "Program Evaluation On Tutor Training At Open University". Jurnal Evaluasi Pendidikan Vol. 2 No. 2, Oktober 2011, 206-217.

Widoyoko, E. P. 2009. Evaluasi Program Pembelajaran: Panduan Praktis Bagi Pendidik Dan Calon Pendidik. Yogyakarta: Pustaka Belajar. 